\title{
Bem versus mal: a transmutação do ethos nas cartas de um assassino confesso
}

\section{Shania Jéssika Cavalcante Rodrigues Gomes}

Mestranda em Linguística pela Universidade Federal de Alagoas, Brasil https://orcid.org/0000-0001-6096-2314

\section{Maria Francisca Oliveira Santos}

Docente da Universidade Federal de Alagoas e da Universidade Estadual de Alagoas, Brasil https://orcid.org/0000-0002-0455-6431

\section{Romildo Barros da Silva}

Doutorando em Linguística pela Universidade Federal de Alagoas, Brasil https://orcid.org/0000-0002-3482-2577

Resumo: Ao revisitar a Antiga Retórica de Aristóteles, aliando-a aos pressupostos da Teoria da Argumentação de Perelman e Olbrechts-Tyteca (2014) e dialogando com os postulados de Meyer (2007), Reboul (1998), Amossy (2005), este trabalho objetiva analisar o processo de transmutação do ethos em duas cartas escritas por Tiago Henrique Gomes da Rocha (THGR), conhecido como o serial killer de Goiânia. Examinaram-se tais cartas, com base em um estudo qualitativo, interpretando-se os aspectos atinentes à constituição e à modificação do ethos retoricamente evidenciado. Para tanto, foram eleitas algumas questões de pesquisa, as quais intentam responder: como, por que e em vista de que ocorre essa transmutação dos diversos tipos de ethé presentes nas cartas analisadas? Em resposta, foi possível concluir que existe uma modificação entre os variados tipos de ethé apresentados, os quais podem ser resumidamente conceituados como "bem" e "mal", que se articulam retoricamente para alcançar a persuasão desejada pelo orador.

Palavras-chave: Carta. Estudo retórico-argumentativo. Persuasão. Transmutação do ethos.

Abstract: By revisiting Aristotle's Old Rhetoric, combining it with the assumptions of Perelman and Olbrechts-Tyteca (2014) Theory of Argument and dialoguing with the postulates of Meyer (2007), Reboul (1998), Amossy (2005), the present work aims at analyzing the transmutation of the ethos in two letters written by Tiago Henrique Gomes da Rocha, better known as the serial killer from Goiânia. In order to do so, two letters written by the accused were examined, based on a qualitative study that interpreted aspects related to the constitution and modification of the rhetorically evidenced ethos. To this end, some research questions were proposed: how, why and in view of what the transmutation of the different types of ethos present in the analyzed letters occurs? In response to these considerations, it was possible to conclude that there is a change between these different types of ethos, which can be briefly conceptualized as "good" and "bad", which are articulated rhetorically to achieve the persuasion desired by the speaker.

Keywords: Letter. Rhetorical-argumentative study. Persuasion. Transmutation of the ethos. 


\section{Introdução}

Da Retórica Clássica aos estudos argumentativos e discursivos modernos, a noção de ethos tem sofrido algumas variações, mas permanece relacionada à figura daquele que se apresenta por meio do discurso (oral ou escrito). Para Aristóteles (Retórica, I, 1358b), o ethos é um dos três elementos essenciais que constituem os meios de persuasão, ao lado do pathos e do logos. Ainda, segundo o mestre de Estagira, ethos representa o elemento cujo caráter pessoal do orador determina. Disso resulta a identificação direta do ethos com a imagem do orador, com os papéis sociais que constituem e personificam tal imagem.

É nessa perspectiva que se pode dizer que, ao se tomar a palavra, seja qual for o meio, o porquê, o tempo ou lugar, se está - de algum modo - criando uma imagem própria, que irá repercutir diretamente em como o interlocutor irá recepcionar e entender esse discurso. É a partir, por exemplo, das concepções de confiança/desconfiança que se aceitam ou não as teses propostas. Essa ideia de construção discursiva do ethos, inclusive, é tratada por Amossy (2005, p. 9), para quem "todo ato de tomar a palavra implica a construção de uma imagem de si".

$\mathrm{Na}$ esteira de tais ponderações, o presente trabalho surge objetivando analisar, sob a perspectiva retórica, de que forma se dá a construção, bem como a transmutação dos diversos tipos de ethé presentes em duas cartas escritas por Thiago Henrique Gomes da Rocha (THGR)' ${ }^{1}$, condenado a aproximadamente seiscentos e cinquenta anos de reclusão pelos assassinatos de 39 pessoas entre os anos de 2011 e 2014, na cidade de Goiânia.

Ao se falar em análise retórica do ethos, está-se querendo dizer que se observará como esse ethos se constitui e se apresenta argumentativamente, com identificação dos elementos retóricos mais conspícuos para a apresentação, constituição e transmutação dos vários tipos de ethé do orador. Para tanto, traz-se como aparato teórico-metodológico a Retórica aristotélica (2011), em estreito diálogo com os estudos da Nova Retórica de Perelman e Olbrechts-Tyteca (2014), Meyer (2007), Reboul (1998), além das concepções de ethos erigidas por Amossy (2005).

Para um melhor recorte do que se avaliará no corpus, o estudo foi direcionado por algumas questões de pesquisa, embasadas em Santos (2011): Como o ethos discursivo se constrói? De quais recursos retóricos se serve o orador no processo de

\footnotetext{
1 Doravante, o autor das cartas será identificado pelas iniciais de seu nome: THGR, bem como pelas palavras 'orador'
} e 'retor', as quais (sem rigor técnico) são usadas como sinônimas no presente trabalho. 
construção de sua imagem? Como e com que finalidade ocorre a transmutação do ethos nas cartas?

Para fins do que se pretende no presente estudo, far-se-á uma correlação estreita entre os meios de persuasão - ethos, pathos e logos - visto que são aqui apreendidos como indissociáveis. Desse modo, a construção do ethos atende a finalidades específicas que se estabelecem por meio de uma estrutura retórica dialógica, na qual o ethos se constitui para o pathos por meio do logos. Está posta a tríade retórica, que pode ser mais facilmente explicada nas seguintes palavras: o orador faz de si uma imagem, a qual deseja que seja vista por seu auditório; com essa imagem, ele pretende comover o auditório de modo a levá-lo, por meio dos argumentos, ao assentimento das teses aventadas. Em uma construção mais direta, Meyer (2007) vai dizer que o ethos se constrói para um pathos.

\section{Ethos, pathos e logos}

Ao instituir as três espécies de provas para o orador atingir a persuasão, Aristóteles (Retórica, I) deixava entrever que são elas elementos interdependentes, que atuam concomitante e complementarmente no discurso. Assim, ao sistematizar analiticamente a Retórica, o filósofo institui os três meios de persuasão que compõem o sistema retórico: ethos, pathos e logos. Os dois primeiros estão relacionados com o caráter afetivo do discurso ${ }^{2}$, ao que se pode chamar de dox $a^{3}$. Eles perfazem a face valorativa da argumentação, enquanto o logos está mais comumente relacionado ao caráter lógico da argumentação (apodítico); etimologicamente falando, logos é o próprio argumento, “palavra”, “discurso”, “razão”.

Assim, o ethos, nas palavras de Aristóteles (Retórica, I, 1, 1356a), é o meio de persuasão que vai depender do caráter pessoal do orador, enquanto o pathos representa o intento de levar o auditório a certa disposição de espírito; e, por fim, o logos é dependente do próprio discurso no que diz respeito ao que demonstra ou parece demonstrar. Ao se depreender o ethos como um dos meios de persuasão, estáse colocando-o no patamar de elemento que possibilita a efetividade da persuasão. Nessa análise, pode-se acrescentar a compreensão da persuasão aventada por Perelman e Olbrechts-Tyteca (2014, p. 31), os quais propõem “chamar persuasiva a uma argumentação que pretende valer só para um auditório particular”.

\footnotetext{
2 Ethos e pathos são de ordem afetiva, enquanto logos é de ordem racional (REBOUL,1998, p. 47)
}

3 Doxa aqui é entendida como "representações partilhadas" (AMOSSY, 2005, p. 125). 
Como dito, há uma espécie de cadeia de entrelaçamentos entre os três meios de persuasão, de modo que um depende do outro: confiar no orador sugere lhe dar maior credibilidade, o que facilita a persuasão por meio de seu discurso, o qual é, por fim, apresentado na forma de argumentos. Tal codependência, inclusive, foi relatada por Meyer (1994, p. 49-50) ao enunciar: "Páthos, lógos e éthos encontram-se sem que possamos nunca os delimitar com precisão. A autojustificação implica argumentos (lógos) mas também ter em conta o outro (páthos) a quem se quer agradar para ser aceito ou a quem se quer manipular (éthos)". Para Meyer (2007), o ethos não se restringe à construção de uma imagem de forma isolada, mas refere-se a um conjunto de caracteres que vão constituí-lo. Para o autor, elementos como caráter, comportamento e até mesmo escolha de vida são responsáveis pela constituição do ethos do orador.

A partir do parágrafo anterior, pode-se inferir que o ethos na Retórica está ligado diretamente ao caráter pessoal do orador, que constrói uma imagem de si com a finalidade de alcançar a persuasão pelo discurso. É nesse sentido que Aristóteles (Retórica, I, 5, 1356a) elucida: “a persuasão é obtida graças ao caráter pessoal do orador, quando o discurso é proferido de tal maneira que nos faz pensar que o orador é digno de crédito". Adiante, o filósofo ainda adverte para o fato de que "não é verdadeiro, como supõem alguns autores em seus tratados sobre retórica, que a honestidade pessoal revelada pelo orador em nada contribui para seu poder de persuasão" (ARISTÓTELES, Retórica, l, 10, 1356a).

Por outro lado, é importante que se tenha por certo o fato de que a imagem representada nem sempre será condizente com a realidade; trata-se aqui de uma projeção de imagem feita intencionalmente pelo orador. Por isso, é importante frisar que nem sempre o ethos representa a imagem real daquele que fala, antes é uma imagem "transvestida", criada por intermédio de uma determinada situação comunicativa e direcionada a interlocutores determinados. Logo, retoricamente falando,

o ethos é tido como a imagem do orador construída perante seu auditório, deixando-se marcar no próprio discurso dos interlocutores. $O$ ethos já não se limita àquele que fala pessoalmente, nem tampouco a um autor de texto, cuja presença pouco importa, ele se apresenta de maneira geral como aquele com que o auditório se identifica e, em última instância, a todos os interlocutores envolvidos no processo de interação verbal (SOUZA; COSTA, 2009, p. 4)

A partir de tais concepções acerca do ethos, fica mais fácil entender quando Aristóteles (Retórica, I, 10, 1356a.) acrescenta: “pode-se considerar o seu caráter [do 
orador], por assim dizer, o mais eficiente meio de persuasão de que dispõe”. Assim é que não apenas o dizer, mas também o modo como é dito, com que argumentos e em vista de que se diz, são elementos fundamentais para inspirar confiança e conseguir a adesão do auditório.

No que concerne ao pathos, este representa um elemento eminentemente passional da tríade aristotélica, isso porque sua própria concepção está relacionada às paixões que o orador suscita no auditório. É, portanto, para quem se dirige o orador que, após fazer a "leitura” de seu público, pode ser capaz de levá-lo ao convencimento. Uma conceituação mais completa e assertiva não poderia advir senão dos precursores da Nova Retórica, para quem o pathos representa um conjunto variável de pessoas que o orador deseja influenciar; é variado porque pode ir desde o próprio orador até toda a humanidade (PERELMAN; OLBRECHTS-TYTECA, 2014).

O discurso argumentativo, então, é tributário de alguém a quem visa persuadir. Tal ideia se coaduna com a perspectiva dialógica da argumentação, visto que "do princípio ao fim, a análise da argumentação versa sobre o que é presumidamente admitido pelos ouvintes" (PERELMAN; OLBRECHTS-TYTECA, 2014, p. 73). Sendo assim, o pathos é o objeto a que se destina o discurso retórico, pois é para ele (auditório) que se dirige a argumentação. É, portanto, essa recepção que determina o objetivo de todo discurso retórico (ARISTÓTELES, Retórica, I). É dizer: o pathos se subsume ao processo argumentativo, do qual se depreende o “outro" sob a perspectiva dialógica da argumentação.

Perfazendo o acabamento da tríade argumentativa, exsurge o logos: a própria argumentação ${ }^{4}$. Em um primeiro momento, parece difícil entender a abstração do conceito de argumento, dando-lhe um status de independência relativa. Tem-se aqui como independência relativa, pois, como dito neste trabalho, os meios de prova não podem, jamais, ser tratados separadamente. Assim, para se firmar uma concepção mais clara sobre o que se entende por logos, utiliza-se a conceituação de argumentação que Perelman (1969) faz ao diferenciá-la da demonstração:

A argumentação, pelo contrário, é essencialmente um ato de comunicação. Implica comunhão de mentes, tomada de consciência comum do mundo, tendo em vista uma ação real; supõe uma linguagem viva, com tudo o que esta comporta de tradição, de ambiguidade, de permanente evolução (PERELMAN, 1969, p. 49-50).

Em uma perspectiva mais sistemática, Perelman e Olbrechts-Tyteca (2014 apud REBOUL, 1998) elege cinco características da argumentação, quais sejam: 1) direção

\footnotetext{
4 Para Reboul (1998), o logos diz respeito à argumentação em si, entendida como prova intrínseca.
} 
para um auditório; 2) expressão em língua natural; 3) verossimilhança nas premissas; 4) progressão dependente do orador; 5) conclusões sempre contestáveis. Salienta-se ainda que são sinônimas as noções de argumentação e logos, por se entender que suas possíveis diferenças não interferem na conceituação de logos referendada neste trabalho. Assim, vê-se que Reboul (1998) descreve o argumento demonstrando as partes que o constituem, e ainda acrescenta ser possível defini-lo como uma proposição destinada a levar à admissão de outra. O logos é, então, o elemento que se volta aos aspectos racionais da argumentação; é o próprio discurso apresentado como aquilo que demonstra ou pretende demonstrar algo (ARISTÓTELES, Retórica, l) sem, no entanto, Ihe atribuir um caráter exclusivamente apodítico e voltado para a doxa, em sua constante interação com os demais meios de prova.

\section{Contextualizando}

Conhecido como maníaco de Goiânia, Tiago Henrique Gomes da Rocha (THGR) foi preso em 2014, enquanto trabalhava como vigilante. À época, o acusado confessou ter assassinado 39 pessoas entre os anos de 2011 e 2014. Posteriormente, em âmbito judicial, ele reduziu sua confissão alegando ser responsável por 29 homicídios. Hoje, após 30 condenações, THGR acumula em sua ficha criminal em torno de seiscentos e cinquenta anos de pena de prisão. Entretanto, ficará preso por, no máximo, 30 anos, visto que, no ordenamento jurídico brasileiro, a pena restritiva de liberdade tem uma limitação legal máxima de 30 anos.

Nesse contexto heterogêneo, em que se entrelaçam questões retóricas, jurídicas, sociais, entre outras, buscar-se-á a identificação do que se registra como sendo possivelmente uma transmutação do ethos a partir da análise das cartas supramencionadas. A primeira foi escrita quando ele ainda não havia sido preso. Tratase, portanto, de carta apócrifa cuja confirmação da autoria só foi possível após a prisão do acusado e o exame forense das digitais deixadas por ele no papel.

A referida carta foi endereçada à Polícia Civil de Goiânia, em 12 de março de 2013. Tratava-se de um suposto assassino que assinava como "Facada" e que reivindicava a autoria de 11 (onze) assassinatos cometidos "de todas as formas". No canto superior direito da carta, há a data de 21 de maio de 2012, mas não se sabe efetivamente se esta é de fato a data quando ela foi produzida, visto que sua postagem apenas ocorreu quase 10 (dez) meses depois, como é possível confirmar através do carimbo dos Correios. 
Como não se tratava de manuscrito, mas de carta produzida digitalmente, não foi possível a realização de exame grafotécnico para determinação da autoria. No entanto, THGR deixou suas impressões digitais no papel; porém, como nunca havia sido preso, não houve compatibilidade imediata daquelas digitais colhidas na carta com as existentes no banco de dados da polícia. Mais de um ano depois, com sua prisão e posterior recolhimento de suas digitais, foi possível a realização do exame que demonstrou a compatibilidade entre as digitas de THGR e as encontradas na carta.

Na segunda carta, enviada ao Tribunal de Justiça de Goiás em 12 de fevereiro de 2016, o orador assina seu verdadeiro nome, identificando-se claramente no início. Como na primeira, há também um auditório específico: os membros do tribunal do júri, sete pessoas escolhidas aleatoriamente, por meio de sorteio, para prolatar o veredito final acerca de sua condenação ou absolvição.

\section{Metodologia e análises}

No presente trabalho, realizou-se uma pesquisa com abordagem qualitativa, na medida em que seu enfoque explica os dados a partir de interpretações que podem propiciar a compreensão do fenômeno social em estudo. Elegeu-se como objetivo de estudo a análise do ethos nas cartas de THGR, mais especificamente sua modificação (transmutação). Esse fenômeno é essencial para o desenvolvimento do próprio gênero (carta) e da inovação desse tipo de estudo (transmutação) aplicado aos gêneros midiáticos.

A escolha do corpus se deu precipuamente quando da repercussão midiática de tais cartas na imprensa nacional, o que trouxe novamente o assunto às manchetes de jornais, em que se noticiou exaustivamente a existência de tais cartas e seu conteúdo. Utilizou-se Godoy (1995) para situar a pesquisa como sendo documental, uma vez que a autora elenca o gênero discursivo "carta" como um dos que constam no rol daquilo que ele chamou de documentos, e complementa ainda acerca da análise:

de materiais de natureza diversa, que ainda não receberam um tratamento analítico, ou que podem ser reexaminados, buscando-se novas e/ou interpretações complementares, constitui o que estamos denominando pesquisa documental (GODOY, 1995, p. 21-22).

Salienta-se, ademais, que o corpus (documentos/cartas) foi interpretado com base em análises retórico-argumentativas, porque apresenta características que permitem estudá-lo tanto pelos postulados da Antiga quanto da Nova Retórica (teoria 
da argumentação). Resolveu-se separar as análises das duas cartas para uma melhor compreensão e visualização da identificação, bem como da transmutação do ethos do orador. Quanto às análises, foi feita a apreciação uma de cada vez, respeitando-se a ordem cronológica de sua escritura.

\subsection{Análise I (carta I)}

Na análise I, observou-se a eleição de um auditório particular ${ }^{5}$ para o qual o orador se destina: a polícia da cidade de Goiânia. A carta se inicia com o seguinte cumprimento: "Cara polícia de Goiânia"; entretanto, ao contrário do que se pode esperar, a saudação utilizada não parece ter o intuito de aproximar o orador do auditório, como comumente se infere de saudações em aberturas de cartas, visto que, no caso em apreço, o termo "Cara” aparenta um caráter irônico.

Em Perelman e Olbrechts-Tyteca (2014, p. 236), a ironia "exige um conhecimento prévio das posições do orador" e é fortalecida "quando é dirigida a um grupo bem delimitado", tal como visto no excerto em análise em que o orador se direciona para um grupo: a Polícia de Goiânia. Reboul (1998), por sua vez, considera a ironia como figura do pensamento, utilizada pelo orador para dizer o contrário daquilo que ele realmente deseja dar a entender. O autor ainda apresenta a ironia como sendo uma figura que pode ser "amena ou cruel" (ibidem, p. 132) e finaliza afirmando: "há sempre uma dose de alegria sádica na ironia, o 'prazer maligno' de ver a bola murchar, de ver o esfrangalhamento das pretensões de poder..." (ibidem, p. 132-133). No caso da saudação que inicia a carta em análise: "Cara polícia de Goiânia", parece haver a antecipação de um ethos irônico, destemido e trocista que se apresenta sarcasticamente.

No corpo da carta, o orador afirma que a utiliza para comunicar que os policias terão ainda muito trabalho a fazer: "Quem vos fala é um cidadão cujo único objetivo é matar". Ao se apresentar como alguém que tem por objetivo matar, nota-se um ethos delinquente, de alguém que se coloca como um assassino, um inimigo ideológico da polícia. Tanto é assim que, para deixar clara sua intenção quanto à imagem que deseja construir perante seu auditório, o orador propõe explicitamente alguns adjetivos para si, identificando-se como “cidadão", "assassino em série”, "serial killer”, "facada”. Por

\footnotetext{
5 Um dos três tipos de auditório teorizados por Perelman e Olbrechts-Tyteca (2014, p. 34), o auditório particular é formado "unicamente pelo interlocutor a quem se dirige [...], cujas reações conhecemos e cujas características somos ao menos capazes de estudar".
} 
meio de tais qualificações, ele parece imprimir para si um ethos temível, incontrolável, que, independente do que seja feito "vai até o fim", como ele mesmo escreveu em outro trecho da carta.

A despeito desse ethos de um assassino sanguinário, primeiramente, THGR se apresenta como "cidadão", o que chama a atenção, por ser uma palavra que está fora do campo semântico das demais palavras que ele utiliza para se nomear, quais sejam: "assassino em série", "serial killer", "facada". Ao contrário dessas últimas, a palavra "cidadão" conclama o ethos da probidade, da honestidade e do respeito; afinal, o senso comum tende a atribuir tais características ao cidadão de modo geral. No caso em epígrafe, pode-se identificar um possível desvio de valores, uma inversão daquilo que seria um "cidadão" para o senso comum, em latente divergência com o que tal palavra deva, provavelmente, significar para o orador, na medida em que ele a equipara às demais citadas acima. O contexto da carta é útil para confirmar o sentido diverso com o qual o retor utiliza o termo "cidadão", dado que na carta tem-se como "cidadão" alguém "cujo único objetivo é matar".

Outro aspecto relevante é a utilização dos termos sinônimos: "assassino em série" e "serial killer". O orador propõe ao seu auditório a possibilidade de utilizar quaisquer desses dois termos para nomeá-lo. Assim, ele diz "sou um assassino em série ou se preferir podem me chamar de serial killer". Ao fazer uso do termo "assassino em série" e, logo em seguida, da sua versão no inglês, lança-se mão de uma figura retórica de presença, especificamente a figura de repetição, a qual tem por objetivo principal deixar claro o ethos discursivo.

As figuras de presença tendem a "tornar presente na consciência o objeto do discurso.” (PERELMAN; OLBRECHTS-TYTECA, 2014, p. 197). No caso da repetição, fica ainda mais notável essa intenção em reforçar o sentimento de presença, o qual é de grande valia para a argumentação. A repetição trazida apresenta termos não idênticos, mas com sentidos aproximados. Todavia, a despeito da aproximação de sentidos existentes entre "assassino em série" e "serial killer", a repetição do segundo enunciado aparentemente reforça o seu valor argumentativo.

De um modo geral, é possível reconhecer ainda a presença de um ethos de afrontamento em que o orador desafia diretamente uma instituição estatal, como é possível observar no seguinte excerto: “Não tentem me parar". Não apenas esse trecho, mas o próprio fato de se apresentar como responsável por assassinatos, bem como afirmar que realizará muitos outros, indica um ethos insultuoso que conclama seu auditório para um embate de forças, para um desafio, o que facilitará a construção que o orador aparentemente deseja apresentar. Para construir esse ethos, THGR utiliza o 
argumento do antimodelo. Para a instauração de tal argumento, "é preciso conhecer certos antecedentes do adversário e/ou comparar situações semelhantes que possam servir de exemplo para os argumentos em desenvolvimento" (SILVA; SANTOS, 2019, p. 105). Trata-se de argumento de significativa relevância, o qual "indica, muitas vezes de modo fortemente emotivo, o que não se deve imitar [...]” (REBOUL, 1998, p. 183).

Ademais, nos trechos "estou evoluindo muito bem" e "Boa sorte à vocês", o orador parece querer assumir novamente um ethos sarcástico e irônico que ele apresenta por meio de um jogo provocativo, no qual utiliza uma postura que pode ser avaliada como sendo típica de alguns criminosos em série ${ }^{6}$. Sua carta, inclusive, sugere ter sido escrita com um estilo típico de serial killers e talvez chegue bem próxima de uma carta conhecida por sua síntese e crueldade, escrita por Jack, que, após assiná-la como “Jack o estripador", ficou mundialmente conhecido.

A carta de Jack inicia com a saudação "Caro chefe" e de forma direta traz promessas de cometimento de novos crimes. Jack ainda desafia a polícia a capturá-lo7. Por certo, não é possível dizer que o orador tenha usado como fonte a supramencionada carta, no entanto, faz-se relevante reconhecer as semelhanças em alguns aspectos, tais como a escolha de um codinome, firmada por uma assinatura como "facada"; a brevidade, a objetividade; bem como a postura austera de afrontamento a qual permeia ambas as cartas.

\subsection{Análise II (carta II)}

Esta segunda carta apresenta uma significativa diferença em relação à primeira devido à sua extensão; se comparada àquela, esta é bem mais longa. Pode-se inferir que isso ocorreu devido ao esforço do ethos em querer projetar-se de maneira distinta daquela apresentada na primeira carta. Entretanto, os critérios de análise foram os mesmos para o corpus em estudo.

Assim como a primeira, a segunda carta também tem auditório certo (particular): os sete membros do Tribunal do Júri, que irão prolatar o veredito de culpado ou inocente em um dos processos em que THGR consta como réu. A carta foi entregue dias antes da sessão de julgamento pela advogada do réu ao juiz responsável pelo caso,

\footnotetext{
${ }^{6}$ De acordo com avaliação psiquiátrica da Junta Médica Oficial do Poder Judiciário de Goiás, Tiago Henrique é portador de uma falha na estruturação do caráter codificada por Transtorno de Personalidade Antissocial (CID-10: F.60.2).

${ }^{7}$ A íntegra da carta de Jack pode ser lida no site https://oaprendizverde.com.br/2014/10/17/goiania-policia-pode-terprendido-o-maior-serial-killer-da-historia-do-brasil/.
} 
que a anexou aos autos do processo, ao qual os jurados tiveram acesso. As semelhanças limitam-se ao aspecto mencionado, divergindo especificamente no objeto de estudo: a transmutação do ethos discursivo por intermédio de argumentos retóricos.

Para encetar a análise, traz-se o seguinte fragmento: "Eu, Tiago Henrique, cumprimento a todos que estão aqui nesse dia importante e agradeço a atenção de cada um de vocês." A abertura da carta agora é não apenas formalmente amistosa, mas efetivamente cordial. O novo ethos exsurge com uma postura educada e respeitosa durante toda a carta. Ao contrário da anterior, não há afronta, nem ironias na saudação que inicia a carta, pois o retor está determinado a utilizar o aspecto agregador da Retórica para suscitar no seu auditório sentimentos de empatia e respeito. Desse modo, deixa transparecer um ethos calmo e ponderado que cumprimenta e agradece em busca de identificação com seu auditório.

Em três momentos diversos, o orador pede desculpas na carta. Isso aparece no primeiro parágrafo, pois ele pede desculpas por não estar usando sua voz, e justificase afirmando que se expressa melhor através da escrita. Adiante, no final da carta, diz: "Do fundo da minha alma eu peço perdão" e, na última linha da carta, acrescenta "Peço Perdão por tudo". Chama-se ordem nestoriana essa ordem de disposição dos argumentos, "segundo a qual cumpre começar e terminar com os argumentos mais fortes” (PERELMAN; OLBRECHTS-TYTECA, 2014, p. 564). Infere-se que alcançar o perdão, portanto, seria um dos principais intentos do orador, visto que ele marca retoricamente seu pedido de desculpas do início ao fim da carta.

Em linhas gerais, o pedido de desculpas é típico de alguém que se arrependeu por seus atos. No caso, o retor quer demonstrar um ethos de remorso, de culpa pelo que fez. Como se trata de réu confesso, THGR não avoca para si a imagem de inocente, mas de arrependido. Um ethos arrependido que "queria voltar ao passado" e que se encontra tão arrependido que chora pelas vítimas: "já chorei muito pelas vidas que se foram". Vê-se que o retor se apresenta como alguém que, ao reconhecer que errou, sofre e sente culpa pelos erros cometidos.

Nesse sentido, o retor intenta construir o ethos da inimputabilidade. O conceito de inimputável é importante para o réu, pois, se ele assim fosse considerado, não receberia pena de reclusão, mas sim medida protetiva do Estado (sanção mais branda). Com vistas a construir um ethos de um doente, de uma pessoa que não era capaz de se determinar de modo diverso, o orador se apresenta como alguém que não pode ser responsabilizado pelos crimes postos em julgamento, como se vê: 
Por que o laudo médico diz que eu supostamente não tenho doença quando na verdade eu preciso tanto de um tratamento?

Por que eles dizem que eu não fazia uso de bebida alcoólica quando na verdade eu estava 'afundado' no alcoolismo?

Por que eles insistem em dizer que sou responsável pelos meus atos quando na verdade tem muitos fatos do meu passado que não me lembro?

Por que eles não citaram todos os transtornos que eu sofri e sofro, como por exemplo a bipolaridade, a audição de vozes, raiva inexplicável, sentimento incontrolável etc. Por quê? ${ }^{8}$

Por meio de questionamentos diretos feitos aos jurados, o ethos demonstrado pelo retor não é mais o de um assassino cruel, mas sim o de uma vítima enferma, que sofre de patologias mentais. Outro argumento que o orador utiliza para se colocar como alguém digno de perdão, e ao mesmo tempo criar um elo com o auditório é o argumento fundado na doxa, ou seja, em uma crença comum existente na opinião pública, ao dizer:

[...] sei que cada um de vocês tem a sua estória de vida, todos passamos por tristezas e alegrias que fazem parte da nossa vida nesse mundo

[...] sinceramente eu queria poder voltar a encontrar a criança que fui no passado.

[...] hoje a única coisa que peço é que tentem me compreender. Compreender meus traumas...

Antes mesmo de apresentar o argumento da doxa em si, fundado no senso comum de que traumas sofridos por crianças podem causar danos incomensuráveis na vida adulta, o orador inicia sua argumentação criando um laço de identidade entre si e seu auditório, colocando-se em patamar de igualdade, pois é presumível que todos tenham um passado, uma infância, que pode até mesmo ter sido traumática. Lançando mão de tais argumentos, o orador visa a um acordo com seu auditório, preconizando a utilização de argumentos que versam "sobre o que é presumidamente admitido pelos ouvintes" (PERELMAN; OLBRECHTS-TYTECA, 2014, p. 73).

Ao dizer: "sei que cada um de vocês tem a sua estória de vida", "todos passamos por tristezas e alegrias que fazem parte da nossa vida nesse mundo", "queria poder voltar a encontrar a criança que fui no passado", "meus traumas...", o orador não explicita nenhum fato concreto, apenas divaga acerca de temas compartilhados pela opinião pública. Acredita-se que, no argumento da doxa, o retor não precisa minudenciar a argumentação posta em voga, visto ser ela embasada em argumentos de fácil aceitação por estarem imiscuídos no seio da comunidade. Nesse ponto,

\footnotetext{
${ }^{8}$ Essas perguntas podem ser caracterizadas como perguntas retóricas, uma vez que demonstram a racionalidade do ethos, indicando, além disso, que o orador tem domínio do discurso, antecipando as respostas do auditório, o que favorece a projeção do seu ethos.
} 
Massmann (2011, p. 374) ensina: "fundamentar a argumentação na doxa significa criar um elo com o auditório, é aproximar-se dele a fim de conquistar a sua adesão às teses apresentadas". Logo, dizer que todos têm um passado, que têm tristezas e alegrias, traumas e coisas do gênero, é amparar a "argumentação nesse conjunto de valores que circula e que, supostamente, é aceito por toda a sociedade" (MASSMANN, 2011, p. 375).

Ainda com o anseio de demonstrar um ethos do bem, de humanidade, o orador atribui à mídia a responsabilidade por ter “criado um monstro". É bem verdade que o aspecto midiático negativo nas coberturas de crimes é tema recorrente, em que se discute a efetiva participação da mídia na formação de culpa dos acusados. Lançando mão de tal argumento, o orador afirma que a mídia construiu uma imagem negativa de si e faz um apelo: "Peço a vocês que olhem para mim neste momento, por favor! O que vocês veem? Vocês veem um ser humano ou um monstro que a mídia criou?"

O ethos em evidência nesse trecho é de alguém que quer ser visto como um ser humano que tanto acerta como erra, mas que não deixa de ser humano. Ele se transveste da imagem de alguém que teria sido injustamente retratado pela mídia como um "monstro" e se coloca em situação de injustiçado, que é visto como ser de categoria inferior (monstro) e diversa daquela que ele acredita que seria justo ser visto (ser humano). Esse é um argumento de vasto valor axiológico, pois o apelo à "regra de justiça requer a aplicação de um tratamento idêntico a seres ou a situações que são integrados numa mesma categoria" (PERELMAN; OLBRECHTS-TYTECA, 2014, p. 248).

Ao final da carta, o orador elege um ethos de bondade, fundamentado na premissa cristã do perdão, que se baseia em um dos mais valiosos bens da humanidade: o amor. Para tanto, ele arremata: "Quero amar vocês, porque condenar se eu posso ajudar?". Entende-se que esse desfecho sugere a tentativa de despertar no auditório as paixões do amor/amizade e da compaixão; assim, ao se apresentar como alguém disposto a amar e ajudar, o orador reivindica um ethos benevolente. O novo ethos do orador é prestativo, inclinado ao bem, o qual não apenas é capaz de ajudar, mas, sobretudo, de amar.

Para uma fácil identificação das mudanças referentes ao caráter do ethos observado em ambas as cartas, faz-se a seguir um quadro-síntese em que são apresentados, de forma objetiva, os principais tipos de ethé analisados. 
Quadro 1 - A transmutação do ethos, mal x bem

\begin{tabular}{ll} 
MAL & BEM \\
\hline Irônico & Educado \\
Delinquente & Respeitoso \\
Temível & Calmo \\
Assassino & Ponderado \\
Afrontoso & Arrependido \\
Insultuoso & Inimputável (doente) \\
Sarcástico & Humano \\
Destemido & Vítima \\
Trocista & Injustiçado \\
Incontrolável & Bondoso \\
& Benevolente \\
& Amoroso \\
\hline
\end{tabular}

Fonte: elaborado pelos autores

Apesar de os diferentes tipos de ethé apresentados acima não estarem, necessariamente, expressos por meio de pares antagônicos, de um modo geral, os da primeira coluna se contrapõem aos da segunda. Nesse sentido, caracteres de ironia, afronta e sarcasmo vão se contrapor aos de educação, respeito e calma. Do mesmo modo, infere-se que se pode contrapor o ethos assassino e delinquente ao ethos de vítima, injustiçado e bondoso que aparecem após a mudança de ethos a que se aludiu neste trabalho. Essa modificação denominada "transmutação" percorre um caminho não linear, quer dizer, não guarda uma correlação de simetria direta entre si. Nesse sentido, é visto, por exemplo, um número maior de caracteres quando se resumiu o "ethos do bem" em detrimento daqueles reservados ao "ethos do mal".

\section{Considerações finais}

Ao percorrer a Antiga Retórica, juntamente com a Nova Retórica, utilizando-as para compreender o modo como se modificam os diversos tipos de ethé nas cartas estudadas, consegue-se identificar aspectos relevantes da construção e transmutação do ethos representado discursivamente. Nesse sentido, são trazidas as questões iniciais de pesquisa, atribuindo-lhes as respostas correspondentes, sintetizando-se o que fora observado nas análises.

Assim, entende-se que os ethé presentes nas cartas se constroem por meio de uma relação direta com o pathos e com o logos, como antimodelo (mal) e como modelo (bem) de bondade e arrependimento. Essa concatenação entre os meios de prova foi 
tratada anteriormente, mas ela é reiterada aqui para confirmar sua importância, uma vez que o orador lança mão de argumentos variados para persuadir seus diferentes auditórios.

A transmutação do ethos nas duas cartas é percebida pelos recursos retóricos utilizados: na primeira carta, o orador emprega recursos linguísticos específicos para compor seu ethos, por intermédio de argumentos que se mantêm em um campo semântico em que se apresenta como "assassino". Essa construção retórica se realiza por meio de uma atividade cíclica, que se realiza em um processo de apresentação e retomada de argumentos, muito embora permaneça buscando sua autoafirmação definitiva de um ethos do mal.

Na segunda carta, o ethos é outro. Agora ele é eminentemente bom e arrependido, disposto, inclusive a ajudar. Nesse sentido, os recursos retóricos aparecem por meio de argumentos que reiteram um discurso linguístico que, a exemplo da primeira carta, também se mantém num mesmo campo semântico e, progressivamente, se orienta para a construção do ethos desejado, mas, ao contrário daquele representado na primeira carta, está pautado no bem.

Observa-se ainda, quando assegurado pelo anonimato, o retor mostra uma face narcisista, de alguém que acredita ser poderoso e inteligente, que se empenhou em criar uma alcunha no intento de construir seu ethos. Por outro lado, quando efetivamente se identifica, o orador se transveste por um ethos totalmente diverso; como anteriormente exposto, bondoso e arrependido. Essa modificação do ethos está diretamente relacionada às intenções do orador: quando acredita que não pode ser identificado, apresenta o ethos do mal; quando deseja absolvição, mostra o ethos do bem. Assim, a dicotomia bem versus mal é o elemento diferenciador das diversas situações do ethos nas cartas estudadas.

Assim, parece ter sido possível alcançar o intento inicial de analisar a transmutação do ethos nas cartas estudadas e mesmo que tais conclusões tenham advindo de uma situação específica, num corpus ímpar, pode-se afirmar que muitos dos seus aspectos basilares devam se repetir em outras situações sociais em que ocorre a modificação do ethos para atender às necessidades imediatas do orador. Desse modo, tendo em vista a importância das questões aqui aventadas, entende-se que seriam de grande valia outros estudos focados não apenas na identificação do ethos em determinados contextos, mas em suas possíveis transmutações e em vista de quais objetivos tais modificações podem ocorrer. 


\section{REFERÊNCIAS}

AMOSSY, Ruth (org.). Imagens de si no discurso: a construção do ethos. 2 ed. São Paulo: Contexto. 2005.

ARISTÓTELES. Retórica. Tradução: Edson Bini. São Paulo: Edipro, 2011 [330-326 a.C.].

GODOY, Arilda Schmidt. Pesquisa qualitativa: tipos fundamentais. RAE - Revista de Administração de Empresas, São Paulo, v. 35, n. 3, p. 20-29, 1995. DOI https://doi.org/10.1590/S0034-75901995000300004.

MASSMANN, Débora Raquel Hettwer. A arte de argumentar em sala de aula. Letras, Santa Maria, v. 21, n 42, p. 363-385, 2011. Disponível em: https://periodicos.ufsm.br/letras/article/view/12187/7581. Acesso em: 16 out. 2020.

MEYER, Michel. As bases da retórica. In: CARRILHO, Manuel Maria (org.). Retórica e comunicação. Tradução: Fernando Marinho. Lisboa: Edições Asa, 1994.

MEYER, Michel. A Retórica. Tradução: Marly Netto Peres. São Paulo: Ática, 2007.

PERELMAN, Chaïm. Le Champ de I'argumentation. Bruxelles: Presses Universitaires de Bruxelles, 1969.

PERELMAN, Chaïm; OLBRECHTS-TYTECA, Lucie. Tratado de argumentação: a nova retórica. Tradução: Maria Ermantina de Almeida Prado Galvão. São Paulo: Martins Fontes, 2014.

REBOUL, Oliver. Introdução à Retórica. Tradução: Ivone Castilho Benedetti. São Paulo: Martins Fontes, 1998.

SILVA, Romildo Barros da; SANTOS, Maria Francisca Oliveira. Argumentos persuasivos do debate político televisivo brasileiro. Maceió: EDUFAL, 2019.

SOUZA, Gilton Sampaio de; COSTA, Rosa Leite da. O professor de Letras e seu discurso: a constituição do ethos de professores do ensino superior. Letra Magna. n. 10, p. 1-16, 2009. Disponível em: http://www.letramagna.com/professorletrasdiscurso.pdf . Acesso em: 18 set. 2020. 


\section{ANEXOS}

Carta 19

Goiânia, 21 de maio de 2012

Cara polícia de Goiânia, venho através desta, comunicar a vocês que nos próximos tempos os senhores terão muito trabalho a fazer. Quem vos fala é um cidadão cujo único objetivo é matar. Serei direto: sou um assassino em série ou se preferir podem me chamar de serial killer, até agora matei apenas 11 pessoas, mas estou evoluindo muito bem. Matei de todas as formas, mas o meu método é esfaquear até a morte, e garanto a vocês que todos os casos não resolvidos de homicídio por esfaqueamento certamente fui eu. Não tentem me parar pois vou até o fim disso. Boa sorte à vocês!. Ass: Facada. Grato.

\section{Carta II10}

Senhores Jurados,

Eu, Tiago Henrique, cumprimento a todos que estão aqui nesse dia importante e agradeço a atenção de cada um de vocês. Peço desculpas por eu não estar usando minha voz, é que na verdade me expresso melhor através da escrita.

Senhora e senhores, sei que cada um de vocês tem a sua estória de vida, todos passamos por tristezas e alegrias que fazem parte de nossa vida nesse mundo.

Amigos jurados, sinceramente eu queria poder encontrar a criança que fui no passado e ter a chance de começar de novo, eu queria poder voltar ao passado no tempo de minha infância e fazer diferente.

Peço a vocês que olhem para mim nesse momento, por favor! O que vocês veem? Vocês veem um ser humano ou um monstro que a mídia criou? O que vocês fariam no meu lugar? Por que o laudo médico diz que eu supostamente não tenho doença quando na verdade eu preciso tanto de um tratamento? Por que eles dizem que eu não fazia uso de bebida alcoólica quando na verdade eu estava "afundado" no alcoolismo? Por que eles insistem em dizer que sou responsável pelos meus atos quando na verdade tem muitos fatos do meu passado que não me lembro? Por que eles não citaram todos os transtornos que eu sofria e sofro, como por exemplo a bipolaridade, audição de vozes, raiva inexplicável, sentimento incontrolável etc. Por quê?

Se tudo isso não for passível de tratamento médico então o que dizer? Será que é preciso mérito na Justiça para se ter uma segunda chance?

9 Carta retirada do site http://g1.globo.com/goias/noticia/2015/03/suposto-serial-killer-enviou-cartas-policia-sedizendo-assassino-em-2013.html Acesso em: 24 de maio de 2020.

10 Carta retirada do site http://g1.globo.com/goias/noticia/2016/02/suposto-serial-killer-envia-carta-juiz-pedindochance-para-recomecar.html Acesso em: 24 de maio de 2020. 
Do fundo da minha alma eu peço perdão às famílias pelo que aconteceu, nada vai mudar isso. Já chorei muito pelas vidas que se foram. Mas hoje a única coisa que peço é que tentem me compreender. Compreender meus traumas, minha sede de ajuda. Será que preciso de mais isolamento? Ainda mais do que fomos intimados? Você que está me ouvindo, o que pensa disso?

$\mathrm{Na}$ prisão não há tratamento para minha doença por isso preciso de um acompanhamento clínico. Peço à sociedade uma chance de me curar e de sorrir novamente.

Quero amar vocês, porque condenar se eu posso ajudar?

Deus abençoe!

Peço Perdão por tudo 